\title{
THE OCCURRENCE OF INTRUSIVE GROWTH ASSOCIATED WITH ARTICULATED LATICIFERS IN TABERNAEMONTANA CATHARINENSIS A.DC., A NEW RECORD FOR APOCYNACEAE
}

\author{
Yve Canaveze $\mathrm{e}^{1, *}$ and Silvia Rodrigues Machado+ \\ *Programa de Pós-graduação em Ciências Biológicas, Departamento de Botânica, Instituto de Biociências, Univ Estadual Paulista (UNESP), \\ 18618-970 Botucatu, São Paulo, Brazil; and +Departamento de Botânica, Instituto de Biociências, UNESP, 18618-970 Botucatu, São Paulo, Brazil
}

Editor: Bruce K. Kirchoff

\begin{abstract}
Premise of research. In Apocynaceae, nonarticulated laticifers have been recorded in most species studied. Interpretation of the mode of development of laticifers, whether articulated or nonarticulated, is controversial, possibly because of the rapid changes that occur in the early differentiation stages of the structures. Here, we describe laticifers in the embryo, seedling, and plant of Tabernaemontana catharinensis A.DC. (Apocynaceae), aiming to understand the structure and developmental mechanism of the laticifer system.
\end{abstract}

Methodology. We prepared samples of mature embryos, 20-d-old seedlings, and 80-d-old plants of $T$. catharinensis according to conventional light microscopy techniques for anatomical and histochemical analysis.

Pivotal results. Articulated anastomosing laticifers with intrusive growth, producing proteins, lipids, and terpenes, are present from mature embryos. Alkaloids are present in the laticifer protoplast of the older portions of the stem. Laticifers of the primary system originate from the ground meristem and procambium, and those of the secondary system originate from the vascular cambium toward the secondary phloem. In the embryo, laticifers are found in the ground meristem and procambium but do not occur in the promeristem; the nodal region exhibits lateral projections between laticifers and ground meristem cells. In seedlings and plants, laticifers are immersed in the parenchyma tissue and associated with the primary and secondary phloem of the root and shoot systems. The anatomical evidence suggests the incorporation of meristematic and parenchyma cells within the laticifer system.

Conclusions. The laticifer system of T. catharinensis has a complex structure and developmental mechanism involving protoplast fusion, the addition of cells, and intrusive growth. We recorded, for the first time, the occurrence of intrusive growth associated with articulated anastomosing laticifers in a member of Apocynaceae. Our findings highlight the importance of detailed anatomical analysis to properly classify laticifers and to access their origin and development.

Keywords: intrusive growth, inducing action, laticifers, ontogeny.

\section{Introduction}

Laticifers are single cells or a series of connected cells containing latex (Fahn 1979; Evert 2006). These structures form an important system of defense against herbivores and microorganisms, act as a sealant against injury, and isolate the chemicals of sensitive plant tissues (Farrell et al. 1991). Laticifers are also critical for taxonomical evaluations (Solereder 1908; Metcalfe and Chalk 1950; Metcalfe 1967; Malhberg 1993; Evert 2006; Demarco and Castro 2008). In addition to the ecological and taxonomic relevance of laticifers, they are also lent considerable economic importance by some of their latex components (Agrawal and Konno 2009).

\footnotetext{
${ }^{1}$ Author for correspondence; e-mail: yve.canaveze@yahoo.com.br.
}

Manuscript received August 2015; revised manuscript received December 2015; electronically published April 20, 2016.
Laticifers are grouped into two types: articulated and nonarticulated. This classification is based on their ontogenesis and structure, and both types vary in the degree of the complexity of their structure (Evert 2006). Articulated laticifers may arise in both the primary and secondary bodies of a plant; these laticifers consist of longitudinal chains of cells in which the walls separating the individual cells remain intact, become perforated, or are completely removed (Esau 1965; Evert 2006). Nonarticulated laticifers typically arise in the primary plant body; they originate from single cells that have continued to grow and do not undergo fusion with other, similar cells (Esau 1965; Evert 2006). Intrusive growth is primarily associated with nonarticulated laticifers. However, both types of laticifer may exhibit this growth mode (Evert 2006).

In Apocynaceae, nonarticulated laticifers have been recorded in most species studied, and articulated laticifers have been described in some species (Demarco and Castro 2008 and the literature cited therein). Interpretation of the developmental mode 
of laticifers is controversial (Demarco et al. 2006; Evert 2006; Demarco and Castro 2008). Divergences in the classification of laticifers probably arise because of the rapid cytological changes that occur in the early stages of differentiation of these secretory structures; thus, ontogenetic studies are needed to determine laticifer type (Milanez 1977).

Tabernaemontana catharinensis A.DC. is a member of Apocynaceae and has a wide geographical distribution that extends to different phytogeographic domains of Brazil (Koch et al. 2015). This species is abundant in areas that have undergone substantial anthropogenic change and occurs in pastures and croplands as well (Pott et al. 2006). Extracts of these plants exhibit trypanocidal (Pereira et al. 1999), leishmanicidal (Soares et al. 2007), antitumoral (Almeida et al. 2004), and antiophidian (Batina et al. 2000; Almeida et al. 2004; Veronese et al. 2005; Gomes et al. 2010) activity. Indole alkaloids, with various pharmacological properties and applications in folk medicine, have also been recorded in T. catharinensis (Pereira et al. 2004; Gonçalves 2011).

In this work, we describe the laticifers in the embryo, seedling, and plant of T. catharinensis A.DC. (Apocynaceae) with the aim of understanding the structure and developmental mechanism of the laticifer system. We record, for the first time, the occurrence of articulated laticifers with intrusive growth in an Apocynaceae member.

\section{Material and Methods}

\section{Plants}

We used the mature embryos, seedlings, and plants of Tabernaemontana catharinensis for this study. All plants were grown under controlled conditions.

The mature embryos $(n=30)$ were obtained from seeds soaked for $36 \mathrm{~h}$ in deionized water (Wilson and Mahlberg 1978). The seeds were removed from the mature fruits of T. catharinensis plants from areas of cerrado (savanna-like vegetation) in the state of São Paulo, Brazil, during the years 2010 and 2011. We deposited specimens in the Herbário Irina Delanova Gemtchújnicov (Herbarium BOTU; nos. 27625-27627).

To obtain seedlings and plants, we removed the arils from seeds $(n=400)$ and placed them in acrylic boxes lined with wet filter paper at $25^{\circ} \mathrm{C} \pm 1{ }^{\circ} \mathrm{C}$ under fluorescent lamps (luminance: $4500-8000 \mathrm{lux}$ ) with a $12 \mathrm{~L}: 12 \mathrm{D}$ photoperiod. Seedlings were transferred to plastic tubes containing vermiculite after root protrusion. The seedlings were maintained under an identical controlled light and temperature regimen for continued vegetative growth and were watered, when necessary, with a nutritive solution (Hoagland and Arnon 1950).

We studied mature embryos, 20-d-old seedlings, and 80-dold plants. Mature embryos are $0.5 \mathrm{~mm}$ long and have two foliaceous cotyledons and a cylindrical embryo axis with an apparent radicular extremity. Twenty-d-old seedlings have two expanded cotyledons, a hypocotyl that is $40 \mathrm{~mm}$ long, and a main root measuring $50 \mathrm{~mm}$. Eighty-d-old plants have senescent cotyledons, a pair of eophylls, and 1-3 pairs of metaphylls. The stem axis (represented by the hypocotyl, epicotyl, and adjacent internodes) measures $80 \mathrm{~mm}$ in length, and the main root is $95 \mathrm{~mm}$ long. In this stage, the plants have secondary tissues.
The term "seedling," as employed here, includes the developmental stages encompassing primary root protrusion until expansion of the first eophyll pair (i.e., the first few leaves with green expanded laminae succeeding the cotyledons; Duke 1965), and the term "plant" includes the developmental stages beginning with the expansion of the first metaphyll pair (i.e., the definitive mature leaves; Duke 1965). We characterized the metaphylls by analyzing the definitive mature leaves of adult plants.

\section{Anatomical and Histochemical Analysis}

We collected intact mature embryos $(n=10)$ and samples from 20-d-old seedlings $(n=10)$ and 80 -d-old plants $(n=10)$. The seedling and plant samples included the shoot apex, with one or two phytomers below the shoot tip; cotyledons; hypocotyls; the transition zone between the root and stem; and the absorption and branching zones of the main root. We also collected samples of eophylls, metaphylls, and epicotyls of plants. A heated knife was used to avoid latex leakage while collecting seedling and plant samples (Milanez 1960/1961).

We fixed the samples in Karnovsky solution (Karnovsky $1965)$ for $24 \mathrm{~h}$ at $25^{\circ} \mathrm{C}$. The samples were then dehydrated in an ethanol series and embedded in methacrylate resin (Leica Microsystems, Heidelberg, Germany). Serial transverse and longitudinal sections ( $5 \mu \mathrm{m}$ thick) were stained in $0.05 \%$ Toluidine blue, $\mathrm{pH} 4.7$ (O'Brien et al. 1964), and the slides were mounted with synthetic resin (Entellan New, Merck, Darmstadt, Germany).

We investigated the classes of compounds present in the protoplast and the composition of the cell wall using histochemical assays on sections of fresh material and fixed samples. Lugol's reagent was used for starch grains (Johansen 1940). Sudan IV (Johansen 1940) and Sudan black (Pearse 1980) were used to detect total lipids. A 7\% cupric acetate solution was used to detect resins (Johansen 1940), Nadi's reagent was used to detect essential oils and oleoresin (David and Carde 1964), Dragendorff's reagent was used for alkaloids (Svendsen and Verpoorte 1983), and a $10 \%$ aqueous solution of ferric chloride was used for phenolic compounds (Johansen 1940). Bromophenol blue was used to detect total protein (Mazia et al. 1953). A $0.02 \%$ aqueous solution of ruthenium red was used to detect pectins (Jensen 1962), and a tannic acid/ferrous chloride 3\% solution was used for mucilage (Pizzolato and Lillie 1973). Periodic acid-Schiff's reagent (McManus 1948) was used to detect total polysaccharides.

We examined and documented all specimens using a light microscope (Olympus BX41) equipped with a digital camera (Olympus C7070).

\section{Results}

\section{Laticifer Distribution and Histochemical Characterization}

Laticifers occur throughout the embryo (fig. 1) and the vegetative body in the seedling and plant (figs. 2-5); they do not invade the promeristem (figs. $1 a, 1 e ; 2 a, 2 b ; 4 a, 4 c$ ).

In the embryo, laticifers occur immersed in the ground meristem (fig. $1 c$ ) and are associated with the procambium (fig. $1 b$ ). In the seedling and plant, laticifers follow the procambial 

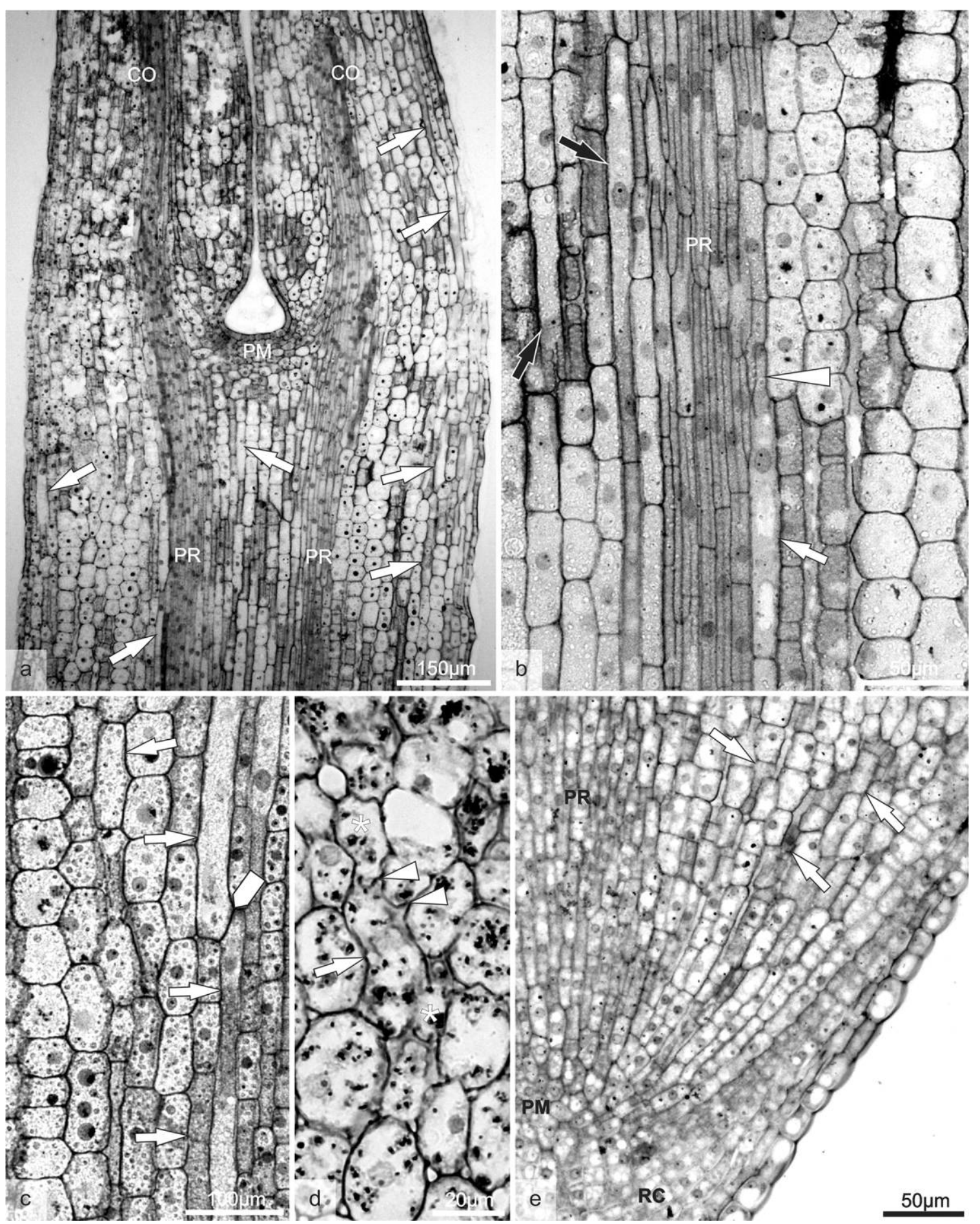

Fig. 1 Distribution and morphology of laticifers in the mature embryo of Tabernaemontana catharinensis. a, A longitudinal section through the embryo depicts laticifers (white arrows) in cotyledons $(\mathrm{CO})$ and hypocotyl associated with ground meristem and procambium (PR). $b$, A longitudinal section through the hypocotyls depicts laticifers (white arrow) associated with external and internal regions of the procambium and laticifers in the pith meristem (black arrows). Note the apical tubular projections (arrowhead) of the laticifer. $c$, A longitudinal section through the hypocotyl depicts laticifers (arrows) with different degrees of axial expansion. Note the contact between lateral longitudinal chains of laticifers through oblique end walls (marker). $d$, A transverse section through the cotyledonary node depicts the formation of lateral projections between the laticifer (arrow) and ground meristem cells (asterisks). Note the laticifer projections (arrowheads) toward adjacent cells. $e$, A longitudinal section through the radicle depicts slender laticifers (arrows). PM: promeristem; RC: rootcap. 

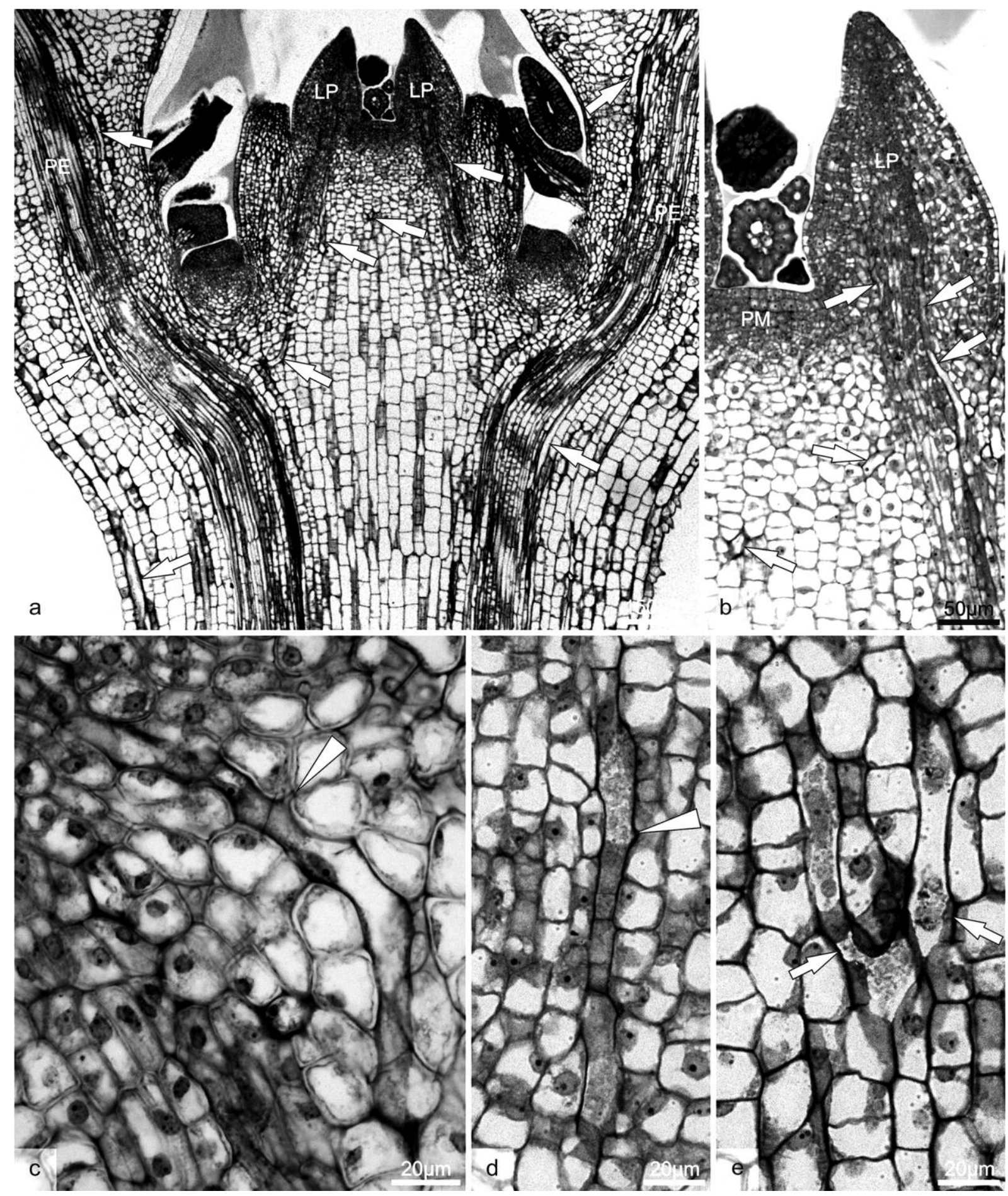

Fig. 2 Longitudinal sections of the shoot system in Tabernaemontana catharinensis: $a, b, d, e, 80$-d-old plant. $c$, 20-d-old seedling. $a$, Shoot apex depicting laticifer (arrows) distribution. Note the laticifers associated with parenchyma and vascular tissues. $b$, Laticifers accompanied the procambial strands that penetrate the leaf primordium (LP). Note the absence of laticifers in the promeristem (PM) region. $c, d$, Longitudinal chains of laticifers. Note the intact or discontinuous end walls, ellipsoid nuclei with evident nucleoli, and short lateral projections (arrowhead) among adjacent cells. $e$, Anastomosing laticifers (arrows). Note disrupted walls among adjacent laticifers. PE: petiole of metaphyll. 

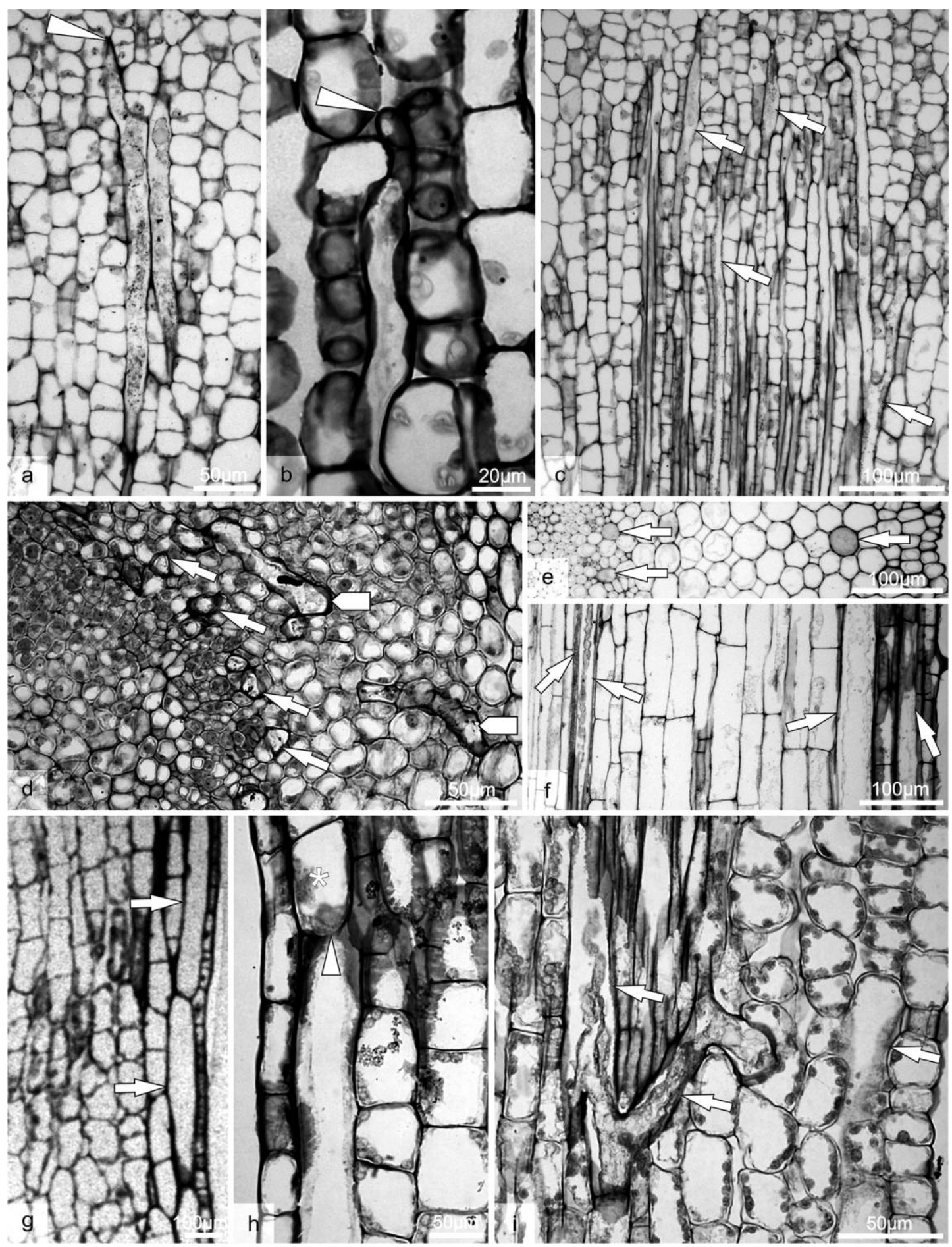

Fig. 3 Distribution and morphology of laticifers in the leaves and stems of Tabernaemontana catharinensis: $a-c, g, 80$-d-old plant. $d-f, h, i$, 20-d-old seedling. $a$, A longitudinal section through a leaf blade in expansion. Note the laticifer with apical projections (arrowhead), nuclei, and no end walls. $b$, A longitudinal section through the epicotyl depicting the tip of a laticifer (arrowhead) penetrating the intercellular space in the cortical parenchyma. $c$, A longitudinal tangential section through the immature internode depicting numerous laticifers (arrows) in the outer region of the vascular cylinder. $d$, A transverse section through an immature internode close to the nodal region. Note the laticifers (arrows) associated with the primary phloem and the laticifer transverse branching (markers). $e, f$, Transversal $(e)$ and longitudinal $(f)$ sections through the hypocotyl. Note that the laticifers (arrows) associated with the parenchyma have a higher diameter than those associated with the primary phloem. $g$, A longitudinal section through the metaphyll petiole. Note the axial sequences of articulated laticifers with intact transverse walls. $h, i$, Longitudinal sections through the cotyledonary blade. $h$, Common discontinuous walls (arrowhead) between the laticifer and the parenchyma cell (asterisk). $i$, Branching laticifer (arrows). 

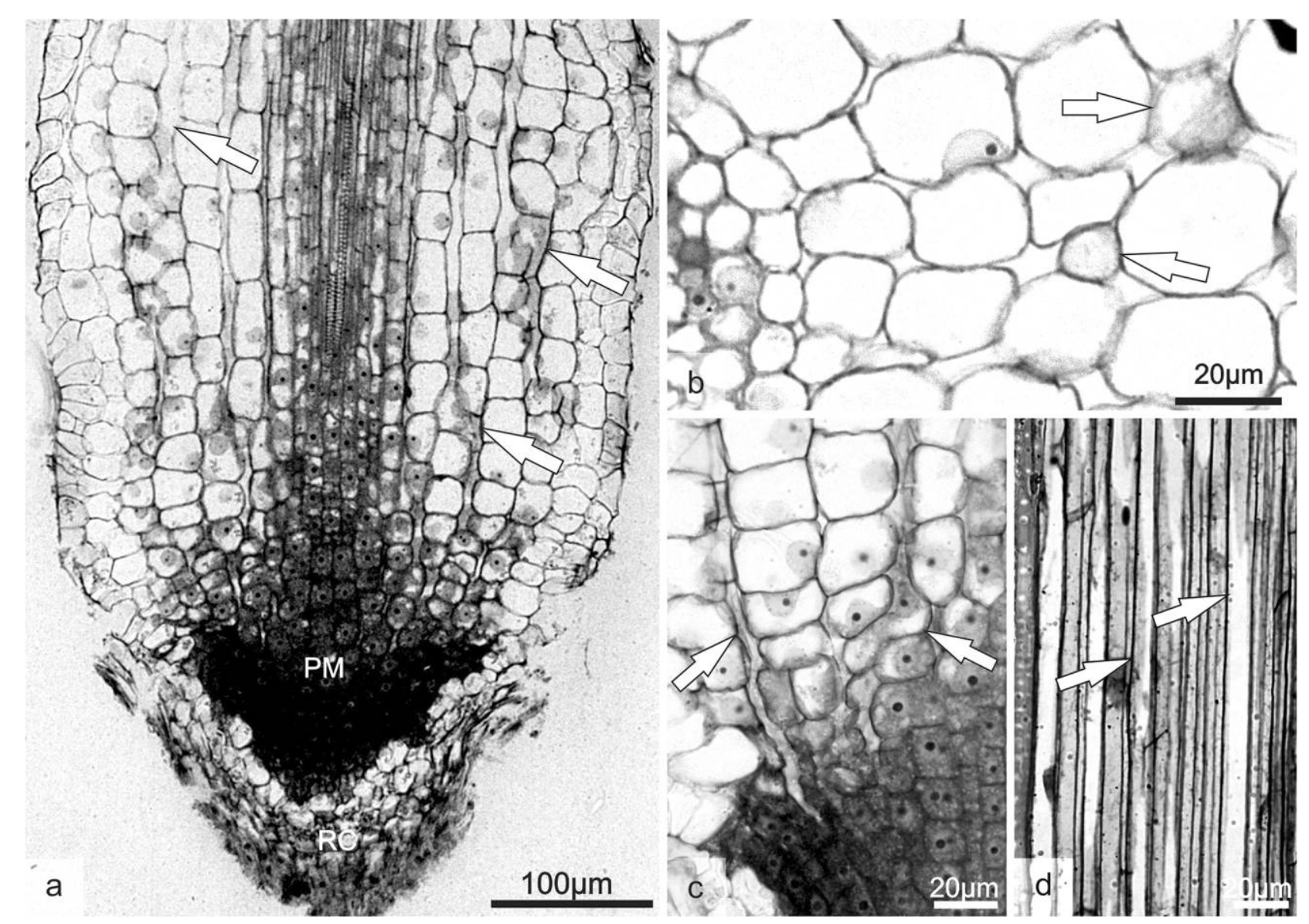

Fig. 4 Distribution and morphology of the laticifers in the main root of Tabernaemontana catharinensis. $a-c, 80-\mathrm{d}$-old plant. $d$, 20-d-old seedling. Longitudinal $(a-c)$ and transverse $(b)$ sections through the root apex depicting laticifers (arrows). $b$, Note laticifers occupying intercellular spaces among the parenchyma cells. $d$, A longitudinal section through the main root differentiated portion depicting laticifers (arrows) associated with the primary phloem. PM: promeristem region.

strands that penetrate the leaf primordium (fig. $2 b$ ). In the vegetative axis of the seedling and plant, they are immersed in parenchyma tissues (cortical, medullary, and mesophyll) and in the primary phloem (fig. $3 e, 3 f$ ). In older stem portions (basal internodes) in 80-d-old plants, laticifers are associated with secondary phloem (fig. 5). Laticifers associated with primary phloem (fig. $3 d-3 f$ ) exhibit a relatively lower diameter than those in the parenchyma tissue (fig. $3 e, 3 f$ ).

Laticifers are abundant in the outer region of the vascular cylinder (fig. $3 c$ ) and are more branched in the nodal regions (figs. $2 e, 3 d$ ). In the leaf blades, procambial laticifers are found growing and branching among the mesophyll cells (fig. $3 i$ ). In the cortical region of the root, laticifers are slender and located in intercellular spaces (fig. $4 a, 4 b$ ).

In all analyzed organs (meristematic and mature portions) and developmental vegetative stages (from mature embryo to plant), laticifers exhibit pectocellulosic cell walls, not lignified or suberized, and the protoplast reacts positively for total lipids, the mixture of essential oils and oleoresins, and protein (table 1). Starch grains are detected in the laticifer protoplast in the seedling hypocotyl and basal internodes of the plant; in this region, alkaloids are also detected (table 1).

\section{Laticifer Origin, Development, and Structure}

In all vegetative developmental stages analyzed (mature embryo, 20-d-old seedlings, and 80-d-old plants), we find articulated anastomosing laticifers with intrusive growth in Tabernaemontana catharinensis.

Laticifers are originated from ground meristematic and procambium cells in the embryo (fig. 1) and in the shoot apex (fig. $2 a, 2 b$ ) and root apex (fig. $4 a, 4 c$ ) in the seedling and plant. In the plant's older stem portions, laticifers originate from fusiform initials of vascular cambium (fig. 5). Ground meristematic (fig. 1d) and parenchyma cells (fig. $3 h$ ) can be incorporated to laticifers.

In the embryo (fig. 1), there are laticifers with different degrees of axial expansion. Laticifers are distinguished from adjacent cells by their axially elongated form, arrangement in longitudinal chains, spherical nucleus, and protoplast with a granular aspect (fig. 1c). The end walls vary from blunt to sharp (fig. 1c). Connections between lateral longitudinal chains of laticifers are observed (fig. $1 c$, marker). As observed in serial longitudinal sections, laticifers exhibit tubular tip projections that intrude among adjacent cells in the procambium region 

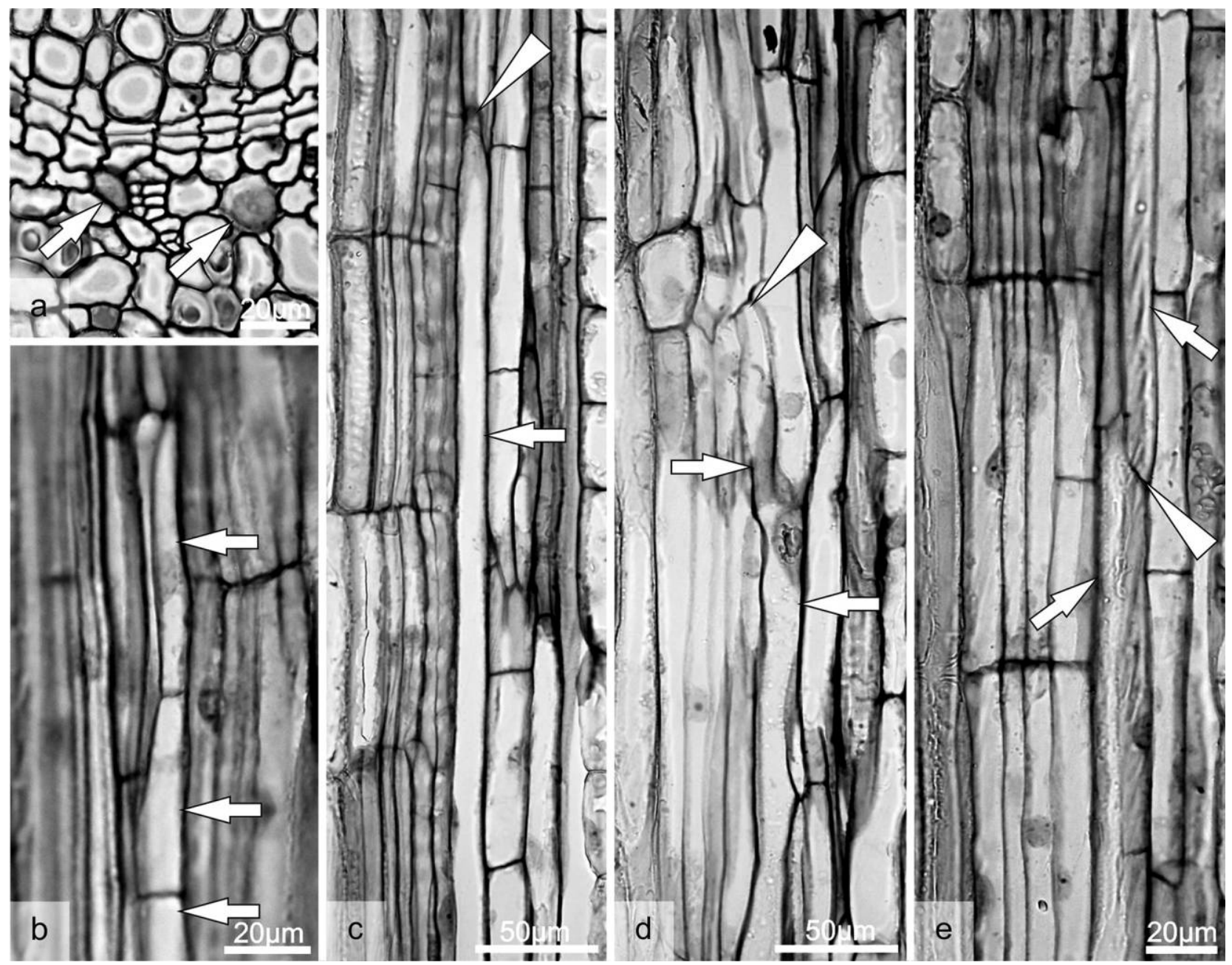

Fig. 5 Secondary laticifer system in the plant stem of Tabernaemontana catharinensis. Transverse $(a)$ and longitudinal $(b-e)$ sections through the hypocotyls of the plant. $a$, Laticifers (arrows) associated with the secondary phloem. $b$, Longitudinal chains of laticifers (arrows). $c, d$, Laticifers (arrows) with tip tubular projections (arrowheads) $e$, Laticifers (arrows) with connected adjacent chains. Note that the transverse cell wall is oblique (arrowhead) between laticifers.

(fig. 1b, arrowhead), indicative of intrusive growth. Branched laticifers are most evident at the cotyledonary node (fig. $1 d$ ), observed in the cross sections. In this region, lateral projections between laticifers and between the laticifers and ground meristematic cells are commonly observed (fig. $1 d$ ), which provides evidence of laticifer branching. Laticifers and meristematic adjacent cells exhibit discontinuous common walls, and these cells became part of the laticifer (fig. $1 d$, asterisk). Laticifers in the radicle are more slender than in other regions of the embryo (fig. 1e).

In seedlings and plants, laticifers do not differ on their origin, development, and structure. Laticifers are distinguishable from the surrounding cells by their elongated form; the granular aspect of their protoplasmic contents; and the presence of one or more nuclei, spherical to ellipsoid in shape, with a distinct nucleolus (fig. $2 c-2 e$ ). Cell walls of laticifers and their adjacent cells are similar in thickness (figs. $3 e-3 h, 4 c$ ), except in the shoot apexes, where laticifers exhibit thickened middle lamella rich in pectins (evidenced by metachromasia with Toluidine blue; fig. $2 c, 2 d$ ).

Commonly, laticifer fusions occur in the same axial series (fig. $2 c, 2 d$ ) or between adjacent laticifers' series (fig. 2e). Protoplast fusions in laticifers with parenchyma cells are also recorded (fig. 3h). Laticifers exhibiting short lateral protuberances (fig. $2 c, 2 d$ ) and tip projections (fig. $3 a$ ), both intruding among adjacent cells, are observed in serial longitudinal sections through the meristematic and elongating regions. Laticifers with tip projections growing into intercellular spaces in the stem cortical parenchyma are also observed (fig. $3 b$ ).

Laticifers with diverse structure are commonly observed in the primary laticifer system, mainly in the shoot apex and in the stem's cortical parenchyma. We identify multinucleated, branched, and elongated cells with a growing tip (we do not observe remnants of septa in these cells; fig. $3 a$ ); axial sequences of rectangular cells with an intact transverse wall (fig. $3 g$ ); elongated cells with anastomoses among adjacent laticifers and dis- 
Table 1

Histochemical Characterization of the Cell Walls and the Protoplast Content of Tabernaemontana catharinensis Laticifers

\begin{tabular}{|c|c|c|c|c|c|c|c|c|c|c|c|}
\hline \multirow[b]{2}{*}{ Reagent } & \multirow[b]{2}{*}{ Substance } & \multirow[b]{2}{*}{$\begin{array}{l}\text { Mature } \\
\text { embryo }\end{array}$} & \multicolumn{3}{|c|}{ 20-d-old seedling } & \multicolumn{6}{|c|}{ 80-d-old plant } \\
\hline & & & Cotyledon & Hypocotyl & $\begin{array}{l}\text { Main } \\
\text { root }\end{array}$ & Cotyledon & Eophyll & Metaphyll & $\begin{array}{c}\text { Internode } \\
\text { close to } \\
\text { shoot } \\
\text { apex }\end{array}$ & $\begin{array}{c}\text { Basal } \\
\text { internodes }\end{array}$ & $\begin{array}{c}\text { Main } \\
\text { root }\end{array}$ \\
\hline \multicolumn{12}{|c|}{ Acidified } \\
\hline $\begin{array}{l}\text { Ruthenium red } \\
\text { PAS }\end{array}$ & $\begin{array}{l}\text { Pectic substances } \\
\text { Noncellulosic }\end{array}$ & CW & CW & CW & CW & CW & CW & CW & CW & $\ddot{\mathrm{CW}}$ & CW \\
\hline & polysaccharides & $\mathrm{CW}$ & $\mathrm{CW}$ & $\mathrm{CW}$ & $\mathrm{CW}$ & $\mathrm{CW}$ & $\mathrm{CW}$ & $\mathrm{CW}$ & $\mathrm{CW}$ & $\mathrm{CW}$ & $\mathrm{CW}$ \\
\hline Sudan IV & Total lipids & $\mathrm{PC}$ & PC & $\mathrm{PC}$ & $\mathrm{PC}$ & $\mathrm{PC}$ & PC & PC & $\mathrm{PC}$ & $\mathrm{PC}$ & $\mathrm{PC}$ \\
\hline Sudan black B & Total lipids & PC & PC & PC & PC & PC & PC & PC & PC & $\mathrm{PC}$ & $\mathrm{PC}$ \\
\hline Nadi's reagent & $\begin{array}{l}\text { Essential oils } \\
\text { and oleoresin }\end{array}$ & PC & PC & PC & PC & PC & PC & PC & PC & PC & $\mathrm{PC}$ \\
\hline $\begin{array}{l}\text { Cupric acetate } \\
\text { Ferric chloride }\end{array}$ & $\begin{array}{l}\text { Resin } \\
\text { Phenolic }\end{array}$ & $\cdots$ & $\cdots$ & $\cdots$ & $\cdots$ & $\cdots$ & $\cdots$ & $\cdots$ & $\cdots$ & $\cdots$ & $\cdots$ \\
\hline Dragendorff's & compounds & $\cdots$ & $\cdots$ & $\cdots$ & $\cdots$ & $\cdots$ & $\cdots$ & $\cdots$ & $\cdots$ & $\cdots$ & $\cdots$ \\
\hline reagent & Alkaloids & $\ldots$ & $\ldots$ & $\ldots$ & $\ldots$ & $\ldots$ & $\cdots$ & $\ldots$ & $\ldots$ & PC & $\cdots$ \\
\hline $\begin{array}{l}\text { Lugol's reagent } \\
\text { Bromophenol }\end{array}$ & Starch grains & $\ldots$ & $\ldots$ & PC & $\ldots$ & $\ldots$ & $\ldots$ & $\ldots$ & PC & PC & $\ldots$ \\
\hline blue & Proteins & PC & PC & PC & PC & $\ldots$ & PC & PC & PC & PC & PC \\
\hline
\end{tabular}

Note. Ellipses indicate no reaction. PAS: periodic acid-Schiff's reagent; CW: positive reaction in the cell wall; PC: positive reaction in the protoplast content.

rupted terminal and lateral walls (fig. $2 c, 2 e$ ); and laticifers and parenchyma cells with discontinuous common walls (fig. $3 h$ ).

Laticifers occurring in the secondary plant body are more linear (fig. 5) - that is, less branched - than those in the primary plant body. Longitudinal chains of cells with intact transverse cell walls (fig. $5 b$ ), laticifers with tubular tip projections (fig. $5 c$, $5 d$ ), and connections between laticifers of adjacent chains (fig. $5 e$ ) occur associated with secondary phloem.

\section{Discussion}

Our detailed study comparing different organs and stages of vegetative growth enables us to access the complexity of the laticifer system in Tabernaemontana catharinensis. Actively secreting laticifers occur from the mature embryo and are present throughout the vegetative axis in T. catharinensis. They are distinguished from other meristematic cells in the embryo and shoot and root apexes by morphological and histochemical characteristics. As recorded for other latex-producing plants (Fahn 1979; Matile 1987; Demarco et al. 2006; Demarco and Castro 2008; Lopes et al. 2009), in T. catharinensis, laticifers differentiate quickly and become secretory early, while the surrounding tissues are still differentiating.

Protein grains, lipid drops, and terpenes were detected in the laticifer protoplast in all analyzed regions of the embryo and the vegetative axis of $T$. catharinensis. This finding is similar to that reported for other latex-producing plants (Evert 2006). The positive reaction to alkaloids in the laticifer protoplast of the older portions of the stem suggests that alkaloids accumulate later in development. Notably, alkaloids were not detected in other cell types. This component of latex merits further inves- tigation due to the fact that the indole alkaloids found in $T$. catharinensis have medicinal applications (Pereira et al. 2004; Gonçalves 2011).

Mature embryos alone can reveal histogenetic evidence of the origin and development of laticifers during embryogenesis (Milanez 1977), and this interesting consideration is supported in our study. Looking at the mature embryo of T. catharinensis, we accessed the laticifer origin, connections and anatomoses between laticifers, evidence of intrusive growth, incorporation of cells to the laticifer system, and laticifers with a smaller diameter in the radicle than other portions of the embryo (as observed in the main root in the seedling and plant). All these diverse features of the laticifer system were common to the seedling and plant of T. catharinensis.

Therefore, our analyses allow us to classify the laticifer system in T. catharinensis as articulated anastomosing laticifers. Currently, Apocynaceae s.l. encompasses five subfamiliesRauvolfioideae, Apocynoideae, Periplocoideae, Secamonoideae, and Asclepiadoideae (Endress and Bruyns 2000) — and the genus Tabernaemontana belongs to Rauvolfioideae. In Apocynaceae, articulated laticifers have been previously recorded in species of Rauvolfioideae (Sacchetti et al. 1999; Demarco et al. 2006), Apocynoideae (Milanez 1977), Periplocoideae (Milanez 1960/ 1961, 1966), and Asclepiadoideae (Demarco et al. 2006; Demarco and Castro 2008). We did not find studies on laticifer anatomy for species of Secamonoideae. Thus, articulated laticifers seem to be distributed through this family.

The presence of the laticifers' intrusive growth is consistent with the tip projections and short lateral protuberances penetrating the middle lamella that cements adjacent cells - observations that have been confirmed by serial anatomical sections analysis. The presence of a thickened and pectin-rich middle 
lamella in laticifers of the shoot apex is also associated with intrusive growth in laticifers (Serpe et al. 2002, 2004). The pectin-rich middle lamella could facilitate the transport of nutrients and water through the cell walls and (or) reduce friction and prevent damage to the cells during laticifer penetration (Serpe et al. 2002). In contrast, the occurrence of laticifers growing into intercellular spaces of $T$. catharinensis provides evidence of tip growth, a growth mechanism exhibited by pollen tubes and root hairs (Evert 2006).

Laticifers that occur in the primary plant body originate from ground meristem and procambium, and new laticifers are continuously added by these meristems to the system in $T$. catharinensis. Similar findings were observed for nonarticulated (Murugan and Inamdar 1987a, 1987b; Appezzato-da-Glória and Estelita 1997) and articulated (Milanez 1959, 1977; Demarco et al. 2006; Demarco and Castro 2008; Lopes et al. 2009) laticifers in Apocynaceae species. In addition, the presence of discontinuous common walls between laticifers and meristematic or parenchyma cells, laticifer projections toward adjacent meristematic cells (as observed in the embryo), and protoplast changes of these cells is evidence of the incorporation of meristematic and parenchyma cells to laticifers in T. catharinensis. These observations suggest an inducing action of laticifers on other cells that undergoes cytoplasmic changes and acquires laticifer features (Milanez 1977). Laticifers' action-inducing mechanism on other cells is still a matter of discussion, and detailed cytological and cytochemical studies are required to clarify this mechanism.
Laticifers that occur in the secondary plant body in T. catharinensis are similar in structure and development to those in the primary body, including with regards to the occurrence of intrusive growth. Our results differ from those of Gimenez (2004), who described articulated, not branching, laticifers in the stem's secondary phloem in T. catharinensis. Our study showed that the laticifer system in T. catharinensis has a complex structure and developmental mechanism involving protoplast fusion, the addition of cells, and intrusive growth. It is important to emphasize that intrusive growth associated with articulated laticifers has been reported in the Euphorbiaceae species (Rudall 1987) but not in Apocynaceae. Therefore, this is the first report of articulated laticifers with intrusive growth in a member of Apocynaceae. Our findings highlight the importance of detailed studies involving embryo, seedling, and plant for the accurate classification of laticifers and to access their origin and development.

\section{Acknowledgments}

We thank the São Paulo Research Foundation (FAPESP) for their financial support (BIOTA Program, process 2008/55434 7) and the doctor's scholarship awarded to Y. Canaveze (process 2012/16441-3). We also thank the National Council for Scientific and Technological Development (CNPq) for the master's scholarship awarded to Y. Canaveze and grants awarded to S. R. Machado.

\section{Literature Cited}

Agrawal AA, K Konno 2009 Latex: a model for understanding mechanisms, ecology, and evolution of plant defense against herbivory. Annu Rev Ecol Syst 40:311-331.

Almeida L, ACO Cintra, ELG Veronese, A Nomizo, JJ Franco, EC Arantes, JR Giglio, SV Sampaio 2004 Anticrotalic and antitumoral activities of gel filtration fractions of aqueous extract from Tabernaemontana catharinensis (Apocynaceae). Comp Biochem Physiol C Toxicol Pharmacol 137:19-27.

Appezzato-da-Glória B, MEM Estelita 1997 Laticifers systems in Mandevilla illustris and M. velutina Apocynaceae. Acta Soc Bot Pol 66:301-306.

Batina MF, AC Cintra, EL Veronese, MA Lavrador, JR Giglio, PS Pereira, DA Dias, SC França, SV Sampaio 2000 Inhibition of the lethal and myotoxic activities of Crotalus durissus terrificus venom by Tabernaemontana catharinensis: identification of one of the active components. Planta Med 66:424-428.

David R, JP Carde 1964 Coloration différentielle des inclusions lipidiques et terpéniques des pseudophylles du Pin maritime au moyen du réactif nadi. C R Acad Sci Paris 258:1338-1340.

Demarco D, MM Castro 2008 Laticíferos articulados anastomosados em espécies de Asclepiadeae (Asclepiadoideae, Apocynaceae) e suas implicações ecológicas. Rev Bras Bot 31:701-713.

Demarco D, LS Kinoshita, MM Castro 2006 Laticíferos articulados anastomosados-novos registros para Apocynaceae. $\underline{\text { Rev Bras Bot }}$ 29:133-144.

Duke JA 1965 Keys for the identification of seedlings of some prominent woody species in eight forest types in Puerto Rico. Ann Mo Bot Gard 52:314-350.

Endress ME, PV Bruyns 2000 A revised classification of Apocynaceae s.l. Bot Rev $66: 1-56$.
Esau K 1965 Plant anatomy. Wiley, New York.

Evert RF 2006 Esau's plant anatomy. Wiley-Interscience, New York. Fahn A 1979 Secretory tissues in plants. Academic Press, London.

Farrell BD, DE Dussourd, C Mitter 1991 Escalation of plant defense: do latex/resin canals spur plant diversification? Am Nat 138:881-900.

Gimenez AM 2004 Anatomia de leño y corteza de Tabernaemontana catharinensis A.DC. (Apocynaceae). Quebracho 11:22-33.

Gomes A, R Das, S Sarkhel, R Mishra, S Mukherjee, S Bhattacharya, A Gomes 2010 Herbs and herbal constituents active against snake bite. Indian J Exp Biol 48:865-878.

Gonçalves DM, JHB Araújo, MS Francisco, MA Coelho, JM Franco 2011 Avaliação da atividade antimicrobiana in vitro do extrato de Tabernaemontana catharinensis A.DC. Rev Bras Planta Med 13:197-202.

Hoagland DR, DI Arnon 1950 The water-culture method for growing plants without soil. Calif Agric Exp Stn Cir 347:1-32.

Jensen WA 1962 Botanical histochemistry: principles and practice. W. H. Freeman, San Francisco.

Johansen, DA 1940 Plant microtechnique. McGraw-Hill, New York. Karnovsky MJ 1965 A formaldehyde-glutaraldehyde fixative of high osmolality for use in electron microscopy. J Cell Biol 27:137-138.

Koch I, A Rapini, AO Simões, LS Kinoshita, AP Spina, ACD Castello 2015 Apocynaceae in Lista de Espécies da Flora do Brasil. Jardim Botânico do Rio de Janeiro. http://floradobrasil.jbrj.gov.br/reflora /floradobrasil/FB4861. Accessed August 7, 2015.

Lopes KLB, M Thadeo, AA Azevedo, AA Soares, RMSA Meira 2009 Articulated laticifers in the vegetative organs of Mandevilla atroviolacea (Apocynaceae, Apocynoideae). Botany 87:202-209.

Mahlberg, PG 1993 Laticifers: an historical perspective. Bot Rev 59: $1-23$.

Matile P 1987 The sap of the plant cells. New Phytol 105:1-26. 
Mazia D, PA Brewer, M Alfert 1953 The cytochemical staining and measurement of protein with mercuric bromophenol blue. Biol Bull 104:57-67.

McManus JFA 1948 Histological and histochemical uses of periodic acid. Stain Technol 23:99-108.

Metcalfe CR 1967 Distribution of latex in the plant kingdom. Econ Bot 21:115-127.

Metcalfe CR, L Chalk 1950 Anatomy of the dicotyledons: leaves, stem and wood in relation to taxonomy with notes on economic uses. Vol II. Claredon, Oxford.

Milanez FR 1959 Contribuição ao conhecimento anatômico de Cryptostegia grandiflora. I. Embrião. Rodriguésia 21/22(33/34):347394.

1960/1961 Contribuição ao conhecimento anatômico de Cryptostegia grandiflora. II. Sobre os laticíferos da estrutura primária. Rodriguésia 35/36:99-128.

— 1966 Contribuição ao conhecimento anatômico de Cryptostegia grandiflora. III. Nota sobre a estrutura secundária. Rodriguésia 25:335-350.

1977 Ontogênese dos laticíferos contínuos de Neridium (Nerium) oleander L. Trabalhos do XXVI Congresso Nacional de Botânica, Rio de Janeiro 1975:343-379.

Murugan V, JA Inamdar 1987 a Oganographic distribution, structure and ontogeny of laticifers in Plumeria alba Linn. Proc Indian Acad Sci (Plant Sci) 97:25-31.

$1987 b$ Studies in the laticifers of Vallaris solanacea (Roth) O. Ktze. Phytomorphol 37:209-214.

O'Brien TP, N Feder, ME McCully 1964 Polychromatic staining of plant cell walls by toluidine blue O. Protoplasma 59:368-373.

Pearse AGE 1980 Histochemistry theoretical and applied: preparative and optical technology. Churchill Livingston, Edinburgh.

Pereira CG, MOM Marques, AS Barreto, AC Siani, EC Fernandes, MAA Meireles 2004 Extraction of indole alkaloids from Tabernaemontana catharinensis using supercritical $\mathrm{CO}_{2}+$ ethanol: an evaluation of the process variables and the raw material origin. I Supercrit Fluids 30:51-61.
Pereira PS, DA Dias, SC Franca, MPA Toldo, S Albuquerque 1999 Trypanocidal activity from Tabernaemontana catharinensis A.DC. Acta Hortic 501:165-170.

Pizzolato TD, RD Lillie 1973 Maye's tannic acid-ferric chloride stain for mucins. I Histochem Cytochem 21:56-64.

Pott A, VJ Pott, TW Souza 2006 Plantas daninhas de pastagem na região dos Cerrados. Embrapa Gado de Corte, Campo Grande.

Rudall PJ 1987 Lacticifers in Euphorbiaceae-a conspectus. Bot Linn Soc 94:143-163.

Sacchetti G, M Ballero, M Serafini, C Romagnoli, A Bruni, F Poli 1999 Laticifer tissue distribution and alkaloid location in Vinca sardoa (Stearn) Pign. (Apocynaceae), an endemic plant of Sardinia (Italy). Phyton 39:265-275.

Serpe MD, AJ Muir, C Andème-Onzighi, A Driouich 2004 Differential distribution of callose and a $(1 \rightarrow 4) \beta$-D-galactan epitope in the laticiferous plant Euphorbia heterophylla L. Int I Plant Sci 165:571-585.

Serpe MD, AJ Muir, A Driouich 2002 Immunolocalization of $\beta$-Dglucans, pectins, and arabinogalactan-proteins during intrusive growth and elongation of nonarticulated laticifers in Asclepias speciosa Torr. Planta 215:357-370.

Soares DC, CG Pereira, MAA Meireles, EM Saraiva 2007 Leishmanicidal activity of a supercritical fluid fraction obtained from Tabernaemontana catharinensis. Parasitol Int 56:135-139.

Solereder H 1908 Systematic anatomy of the dicotyledons. Vol 1, 2nd ed. Clarendon, Oxford.

Svendsen AB, R Verpoorte 1983 Chromatography of alkaloids. Elsevier, New York.

Veronese EL, LE Esmeraldino, AP Trombone, AE Santana, GH Bechara, I Kettelhut, AC Cintra, JR Giglio, SV Sampaio 2005 Inhibition of the myotoxic activity of Bothrops jararacussu venom and its two major myotoxins, BthTX-I and BthTX-II, by the aqueous extract of Tabernaemontana catharinensis A.DC. (Apocynaceae). Phytomedicine 12:123-130.

Wilson KJ, PG Mahlberg 1978 Ultrastructure of non-articulated laticifers in mature embryos and seedlings of Asclepias syriaca L. (Asclepiadaceae). Am I Bot 65:98-109. 